\title{
Anti-inflammatory effects of guggulsterone on murine macrophage by inhibiting LPS-induced inflammatory cytokines in NF- $\mathrm{KB}$ signaling pathway
}

\author{
This article was published in the following Dove Press journal: \\ Drug Design, Development and Therapy \\ I June 2016 \\ Number of times this article has been viewed
}

\author{
Jin-Hua Zhang ${ }^{1,2, *}$ \\ Zhao-Shui Shangguan ${ }^{3, *}$ \\ Chao Chen ${ }^{4}$ \\ Hui-Jie Zhang ${ }^{4}$ \\ Yi Lin' \\ 'College of Chemical Engineering, \\ Huaqiao University, ${ }^{2}$ Department \\ of Pharmacy, Xiamen Medical \\ College, ${ }^{3}$ Central Laboratory, The \\ First Affiliated Hospital of Xiamen \\ University, ${ }^{4}$ Xiamen Diabetes \\ Institute, The First Affiliated Hospital \\ of Xiamen University, Xiamen, \\ People's Republic of China \\ *These authors contributed equally \\ to this work
}

\begin{abstract}
The present study was aimed to investigate the effects of guggulsterone (GS) on proinflammatory responses as well as the underlying molecular mechanisms in macrophage upon lipopolysaccharide (LPS) stimulation. Effects of GS on viability of Raw264.7 cells were examined using 3-(4,5-dimethylthiazol-2-yl)-2,5-diphenyl tetrazolium bromide (MTT) assay. Real-time polymerase chain reaction (PCR) was employed to examine the mRNA expression of cytokines, including interleukin $1 \beta$ (IL-1 $\beta$ ), tumor necrosis factor-alpha (TNF- $\alpha$ ), and inducible nitric oxide synthase (iNOS). Phosphorylations of extracellular signal-regulated kinase (ERK), c-Jun N-terminal kinase (JNK), p38 mitogen-activated protein kinases (p38), and inhibitor of nuclear factor kappaB $(\mathrm{I} \kappa \mathrm{B})$ were determined using immunoblotting. The results revealed that GS was not toxic to Raw264.7 cells at designated concentrations. We demonstrated that GS significantly suppressed the elevated mRNA expression of proinflammatory cytokines, including IL-1 $\beta$, TNF- $\alpha$, and iNOS in a dose-dependent manner. GS treatment reduced the level of I $\mathrm{B}$ phosphorylation in LPS-stimulated macrophages in a dose-dependent manner. Use of BAY 11-7082, an inhibitor of nuclear factor-kappaB (NF- $\mathrm{KB}$ ), led to significantly suppressing effects on IL- $1 \beta$ and TNF- $\alpha$ expression similar as that of GS-treated cells. Our findings suggest that GS possesses anti-inflammatory activity, which may be attributed to downregulation of iNOS and inhibition of NF-KB activity in LPS-stimulated Raw264.7 cells.
\end{abstract}

Keywords: Anti-inflammatory effects, guggulsterone, lipopolysaccharides, NF- $\kappa B, I L-1 \beta, T N F-\alpha$

\section{Introduction}

Inflammation is considered as a protective response against diverse pathogens or deteriorating stimuli. It is tightly regulated by an orchestra of cellular and soluble mediators. Inflammatory responses are initiated and propagated by cellular sensing systems such as toll-like receptor system (TLR) and production of inflammatory mediators such as inducible nitric oxide (NO), interleukin $1 \beta$ (IL-1 $\beta$ ), and tumor necrosis factor-alpha (TNF- $\alpha)$. ${ }^{1}$ These soluble mediators play crucial role in controlling inflammation and tissue repair; however, aberrant production may exacerbate the damages.

Macrophages play a pivotal role in inflammatory process. Upon inflammation, these phagocytic cells are activated depending on stimuli and molecular pattern of recognition. ${ }^{2}$ Activation of macrophage through pattern recognition receptor such as TLR leads to the production of a variety of mediators, including NO, TNF- $\alpha$, and IL-1 $\beta .^{3}$ Macrophage-derived NO is synthesized by inducible NO synthase (iNOS). Excessive production of NO contributes to the pathogenesis of chronic inflammatory
Correspondence: Yi Lin College of Chemical Engineering, Huaqiao University, 668 Jimei Road, Jimei District, Xiamen 36102I, People's Republic of China Email lyhxm@hqu.edu.cn
Drug Design, Development and Therapy 2016:10 1829-1835

1829

Dovepress

http://dx.doi.org/1 0.2147/DDDT.S104602 (c) (7) (5) 2016 Zhang et al. This work is published and licensed by Dove Medical Press Limited. The full terms of this license are available at https://www.dovepress.com/terms.php $\mathrm{BY} \mathrm{NC}$ and incorporate the Creative Commons Attribution - Non Commercial (unported, v3.0) License (http://creativecommons.org/licenses/lby-nc/3.0/). By accessing the work you
hereby accept the Terms. Non-commercial uses of the work are permitted without any further permission from Dove Medical Press Limited, provided the work is properly attributed. For permission for commercial use of this work, please see paragraphs 4.2 and 5 of our Terms (https://www.dovepress.com/terms.php).
her 
disorders. ${ }^{4,5}$ Additionally, TNF- $\alpha$ and IL-1 $\beta$ are produced in activated macrophages, in turn, to facilitate and amplify cytokines and chemokine production in chronic inflammatory setting. Lipopolysaccharide (LPS), a component of Gram-negative bacteria cell wall, is known as the ligand of TLR4. Recognition of LPS by TLR4 in macrophages initiates downstream signaling pathways including nuclear factor-kappaB (NF-кB) complex and mitogen-activated protein kinases (MAPKs), such as p38 MAPKs (p38), c-Jun $\mathrm{N}$-terminal kinase (JNK), and extracellular-signal regulated kinase (ERK). ${ }^{6,7} \mathrm{NF}-\kappa \mathrm{B}$ is reported to play a critical role in acute and chronic inflammatory conditions. It is considered as a potential target for anti-inflammatory drug development.

Guggulsterone (GS) is a phytosterol that is found enriched in Commiphora mukul. It is reported as an antagonist of farnesoid $\mathrm{X}$ receptor and demonstrated hypolipidemic activity. ${ }^{8}$ GS has been demonstrated to exert a range of pharmacological activities, including antineoplastic, antioxidation, antidiabetic, and cardioprotection. ${ }^{9-13}$ GS attenuates colitis in mice through inhibition of NF- $\kappa \mathrm{B}$ activation. ${ }^{14,15}$ Researches have shown that GS inhibits proliferation of tumor cells through induction of apoptosis and inhibition of NF- $\mathrm{BB}$ signaling pathway. ${ }^{16-18}$ It is of interest to determine the effects of GS on LPS-induced inflammation in lymphocytes.

In this study, we investigated the anti-inflammatory effects and the underlying mechanism of GS, in particular gene expression of iNOS, IL-1 $\beta$, and TNF- $\alpha$ in LPS-stimulated Raw264.7 cells. We also examined the role of NF- $\mathrm{BB}$ in LPS-induced inflammatory response in macrophages.

\section{Materials and methods}

\section{Cell culture}

Murine macrophage-like cell line (Raw264.7) was obtained from ATCC and incubated in complete Dulbecco's Modified Eagle's Medium (DMEM; Thermo Fisher Scientific, Waltham, MA, USA) containing $0.1 \%$ sodium bicarbonate, $2 \mathrm{mM}$ glutamine, $100 \mathrm{U} / \mathrm{mL}$ penicillin $\mathrm{G}$, streptomycin $(100 \mu \mathrm{g} / \mathrm{mL})$, and $10 \%$ fetal bovine serum (FBS) at $37^{\circ} \mathrm{C}$.
For GS treatments, Raw264.7 cells were seeded and incubated overnight prior to the treatments. Cells were treated with $\mathrm{GS}(0,1,5,10$, and $25 \mu \mathrm{M})$ for 24 hours (cell viability assay), 2 hours (real-time polymerase chain reaction [PCR] analysis), and 4 hours (immunoblotting), respectively, with or without a subsequent exposure to $1 \mu \mathrm{g} / \mathrm{mL}$ LPS. GS samples were prepared and added to the culture medium at a final concentration of $0.1 \%(\mathrm{v} / \mathrm{v})$ in dimethyl sulfoxide (DMSO). DMSO with a final concentration of $0.1 \%$ was used as blank control.

\section{Cell viability}

Raw264.7 cells were seeded and incubated overnight prior to the treatments and then was followed by a treatment with GS $(0,1,5,10$, and $25 \mu \mathrm{M})$ for 24 hours. Cell viability was determined using 3-(4,5-dimethylthiazol-2-yl)-2,5-diphenyl tetrazolium bromide (MTT) assay. In brief, $10 \mu \mathrm{L}$ of MTT solution $(5 \mathrm{mg} / \mathrm{mL}$ in complete DMEM) was added to the medium followed by an incubation time of 4 hours at $37^{\circ} \mathrm{C}$. Following aspiration of the medium, cells were lyzed with 2-propanol which solubilized intracellular formazan. The optical density of formazan was measured using a microplate reader at a wavelength of $570 \mathrm{~nm}$.

\section{Real-time PCR}

Raw264.7 cells were seeded at a concentration of $1 \times 10^{6}$ cells $/ \mathrm{mL}$ and incubated overnight prior to the treatments. Cells were treated with GS $(0,1,5,10$, and $25 \mu \mathrm{M})$ for 2 hours followed by an exposure to $1 \mu \mathrm{g} / \mathrm{mL}$ LPS for 2 hours. Total RNA was isolated from each sample using RNA simple Total RNA Kit (Tiangen, BJ, People's Republic of China) as per the instruction of manufacturer. The resulting RNA was used as a template for generating first-strand cDNA synthesis using ReverTra Ace Kit (Toyobo, Osaka, Japan). The sequences of primers used for reverse transcription PCR (RT-PCR) are shown in Table 1. RT-PCR experiments were carried out using real-time PCR Master Mix (Toyobo) in triplicates for each sample. The threshold cycle numbers

Table I List of RT-PCR primers

\begin{tabular}{|c|c|c|}
\hline Gene & Forward primer & Reverse primer \\
\hline GAPDH & 5'-TGACCACAGTCCATGCCATC-3' & 5'-GACGGACACATTGGGGGTAG-3' \\
\hline IL-I $\beta$ & 5'-GCAACTGTTCCTGAACTCAACT-3' & 5'-ATCTTTTGGGGTCCGTCAACT-3' \\
\hline$T N F-\alpha$ & 5'-GACGTGGAACTGGCAGAAGAG-3' & 5'-TTGGTGGTTTGTGAGTGTGAG-3' \\
\hline iNOS & 5'-GTTCTCAGCCCAACAATACAAGA-3' & 5'-GTGGACGGGTCGATGTCAC-3' \\
\hline
\end{tabular}

Abbreviations: RT-PCR, reverse transcription polymerase chain reaction; GAPDH, glyceraldehyde 3-phosphate dehydrogenase; IL-I $\beta$, interleukin I $\beta$; TNF- $\alpha$, tumor necrosis factor-alpha; iNOS, inducible nitric oxide synthase. 
were determined based on the $\Delta \Delta \mathrm{CT}$ relative value and the cycle number was normalized to that of glyceraldehyde 3-phosphate dehydrogenase (GAPDH). The PCR products were examined and confirmed for the size using agarose gel electrophoresis.

\section{Immunoblot assay}

Raw264.7 cells were seeded at a concentration of $1 \times 10^{6}$ cells $/ \mathrm{mL}$ and incubated overnight prior to the treatments. Cells were treated with GS $(0,1,5,10$, and $25 \mu \mathrm{M})$ for 4 hours followed by an exposure to $1 \mu \mathrm{g} / \mathrm{mL}$ LPS for 30 minutes. After treatments, cells were harvested and washed twice with ice-cold PBS, followed by lysis using RIPA buffer (Thermo Fischer Scientific, Waltham, MA, USA). The resulting lysates were subjected to centrifugation at $13,000 \mathrm{rpm}$ for 10 minutes at $4^{\circ} \mathrm{C}$. The supernatants were obtained and protein concentrations were measured using BCA protein assay kit (Pierce, Rockford, IL, USA). Thirty micrograms of protein was loaded in each lane and was subjected to $12.5 \%$ SDS-PAGE followed by a transfer onto a polyvinylidene difluoride (PVDF) membrane (EMD Millipore, Billerica, MA, USA). Resulting blots were incubated with $5 \%(\mathrm{w} / \mathrm{v})$ skimmed milk in PBS followed by incubation with $1 / 1,000$ dilution of antibodies against

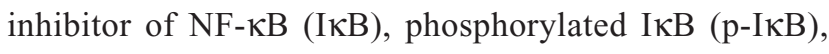
JNK, phosphorylated-JNK (p-JNK), p38, phosphorylated p38 (p-p38), ERK1/2, and phosphorylated ERK1/2 (p-ERK1/2) (Cell Signaling Technologies, Danvers, MA, USA) as well as GAPDH (Santa Cruz Biotechnology Inc., Dallas, TX, USA). The antigen-antibody complexes were unveiled using 1/2,000 dilution of peroxidase-conjugated secondary antibodies (Abcam, Cambridge, UK) and a chemiluminescence substrate (EMD Millipore).

\section{Statistical analyses}

All the data were presented as mean \pm standard deviation (SD) of triplicate experiments. A one-way analysis of variance (ANOVA) with a Duncan multiple-comparison test was utilized to determine statistical differences among the groups. $P$-values $<0.05$ were considered statistically significant.

\section{Results}

\section{Effects of GS on cell viability of murine macrophage Raw 264.7 cells}

To determine the cytotoxic effects of GS, Raw264.7 cells were exposed to $\mathrm{GS}$ at serial concentrations $(0,1,5,10$, and $25 \mu \mathrm{M})$ and determined for the viability using MTT assay. We found that GS exerted nontoxic effects on Raw264.7 cells at designated concentrations as high as $25 \mu \mathrm{M}$ (data not shown).

\section{GS inhibited LPS-induced mRNA expression of IL-I $\beta$,TNF- $\alpha$, and iNOS in Raw264.7 cells}

We next investigated whether treatment with GS alters the expression of proinflammatory cytokines in LPS-stimulated macrophage. mRNA expressions of IL- $1 \beta$, TNF- $\alpha$, and iNOS in LPS-treated Raw264.7 cells were determined using realtime PCR. Results of real-time PCR analysis revealed that mRNA expressions of IL-1 $\beta$, TNF- $\alpha$, and iNOS in Raw264.7 cells were significantly enhanced in the presence of LPS, and the elevated mRNA expressions were suppressed in response to GS pretreatment in a dose-dependent manner (Figure 1).

\section{GS inhibited LPS-induced NF-KB pathway in Raw264.7 cells}

It is evident that GS exerts its pharmacological effects through manipulating NF- $\kappa \mathrm{B}$ pathway. Phosphorylation of I $\kappa \mathrm{B}, \mathrm{NF}-\kappa \mathrm{B}$ inhibitor, is concomitantly required with nuclear translocation of NF- $\mathrm{KB}$. We hence investigated the effect of GS on LPS-induced phosphorylation of IאB in Raw264.7 macrophages. The results showed that Raw264.7 cells exhibited an increased phosphorylation of IKB in response to LPS stimulation (Figure 2A). The elevated IKB phosphorylation was inhibited by GS in a dose-dependent manner. Inhibition of NF- $\mathrm{KB}$ using BAY 11-7082 $(10 \mu \mathrm{M})$, a commercially available inhibitor of $\mathrm{NF}-\kappa \mathrm{B}$, led to a significant decrease in the LPS-induced IL- $1 \beta$ expression, whereas GS showed comparatively less suppression effects (Figure 2B). GS treatment significantly decreased the expression of TNF- $\alpha$ in LPS-stimulated macrophages, while BAY 11-7082 also exerted similar inhibitory activity (Figure 2C).

\section{Effects of GS on phosphorylation of ERKI/2, JNK, and p38 in LPS-stimulated Raw264.7 cells}

Activation of ERK1/2, JNK, and p38 is suggested to be involved in excessive production of proinflammatory cytokines in presence of LPS. We examined the effects of GS on phosphorylation of ERK1/2, JNK, and p38 in LPS-stimulated Raw264.7 cells. As shown in Figure 3, exposure to LPS led to significantly increased phosphorylation of ERK1/2, JNK, and p38 in Raw264.7 cells. Treatment of LPS-stimulated Raw264.7 cells with GS at $1,2.5,5,10,12.5$, and $25 \mu \mathrm{M}$ 
A

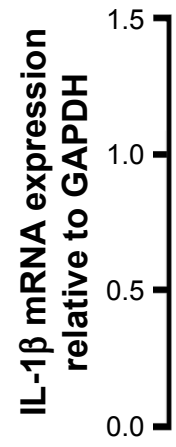

LPS $(1 \mu \mathrm{g} / \mathrm{mL})$ Guggulsterone $(\mu \mathrm{M})$
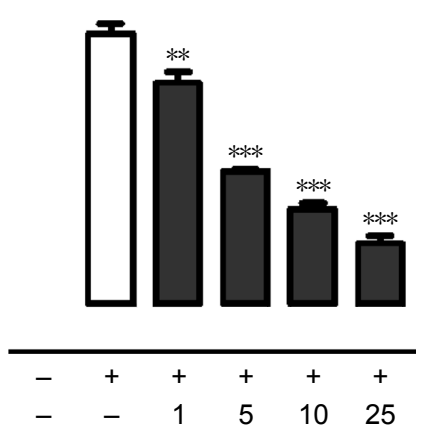

B

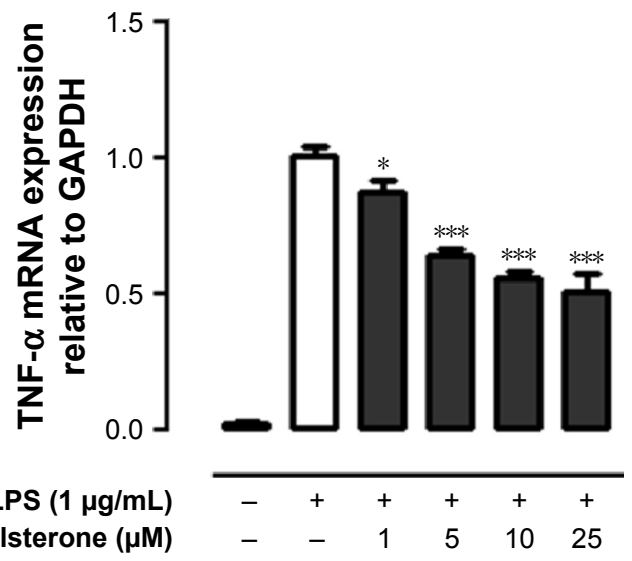

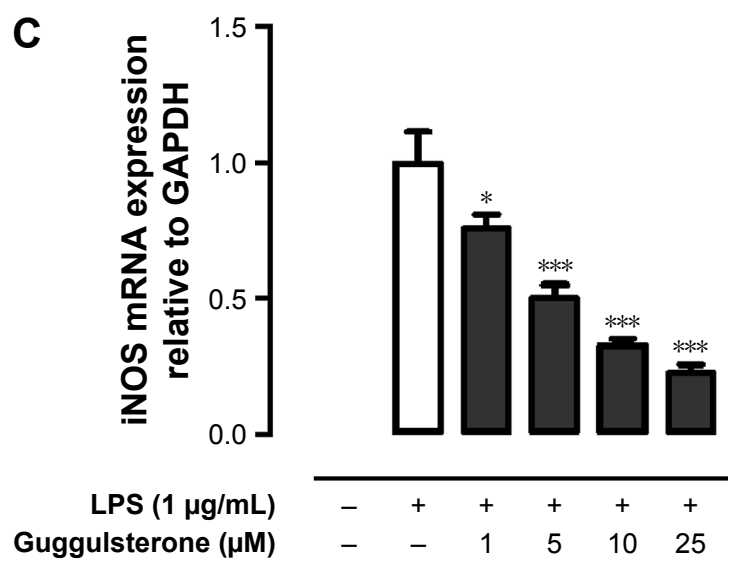

Figure I GS suppressed mRNA expression of proinflammatory cytokines IL-I $\beta$, TNF- $\alpha$, and iNOS in LPS-stimulated Raw264.7 cells.

Notes: Cells were pretreated with GS at indicated concentrations (I, 2.5, 5, I0, 12.5, and $25 \mu \mathrm{M})$ for 2 hours, then cells were challenged with I $\mu \mathrm{g} / \mathrm{mL}$ LPS for 2 hours. After treatments, the cells were lysed for mRNA extraction and gene expression level was analyzed by real-time PCR. mRNA expression of (A) IL-I $\beta$, (B)TNF- $\alpha$, and (C) iNOS is presented. Data are shown as relative fold change after normalization to GAPDH and expressed as mean \pm SD of the three independent experiments. $* P<0.05$ as compared to LPS alone. $* * P<0.01$ as compared to LPS alone. $* * * P<0.001$ as compared to LPS alone.

Abbreviations: GS, guggulsterone; IL-I $\beta$, interleukin I $\beta$; TNF- $\alpha$, tumor necrosis factor-alpha; iNOS, inducible nitric oxide synthase; LPS, lipopolysaccharide; PCR, polymerase chain reaction; GAPDH, glyceraldehyde 3-phosphate dehydrogenase; SD, standard deviation.

concentrations resulted in no change in the levels of $\mathrm{p}-\mathrm{ERK} 1 / 2$, p-JNK, and p-p38 in comparison to LPS alone.

\section{Discussion}

In the present study, we demonstrated that GS significantly suppressed elevated production of proinflammatory mediators in LPS-stimulated Raw264.7 cells. The GS-induced downregulation of chemokine expression was associated with inhibition of NF- $\kappa$ B activation induced by LPS in macrophages. Moreover, GS had no effects on the LPS-induced phosphorylation of MAP kinase family members, including ERK1/2, JNK, and p38.

Macrophages are known to play a fundamentally critical role in the inflammatory response through producing a variety of mediators and proinflammatory cytokines depending on stimuli. A prolonged activation of macrophages results in a dysregulated inflammatory mediator production, leading to a vicious cycle of chronic inflammation. ${ }^{19}$ LPS is recognized by TLR4 in association with MD2 and CD14 in macrophages. LPS-induced activation of TLR4 signaling is known to trigger the release and mRNA accumulation of critical proinflammatory cytokines, including IL- $1 \beta$, TNF- $\alpha$, and iNOS. ${ }^{20-22}$ We showed that the upregulated mRNA expression of IL-1 $\beta$, TNF- $\alpha$, and iNOS in LPS-stimulated Raw264.7 cells was abolished in the presence of GS. The finding is consistent with previous research in which GS suppresses the activation of transcription factor IRF3 induced by LPS. ${ }^{23}$ The LPS-induced activation of TLR4 leads to both early and late activation of NF- $\kappa \mathrm{B}$ through MyD88- and TRIF-dependent signaling pathways, respectively. ${ }^{24,25}$ Our data showed that GS was unable to fully exert its inhibitory effects on TNF- $\alpha$ expression in LPS-stimulated Raw264.7 cells. It is indicated that the inhibitory effect of GS in LPSstimulated macrophages might be attributed to a later step in the NF- $\kappa \mathrm{B}$ activation cascade. 


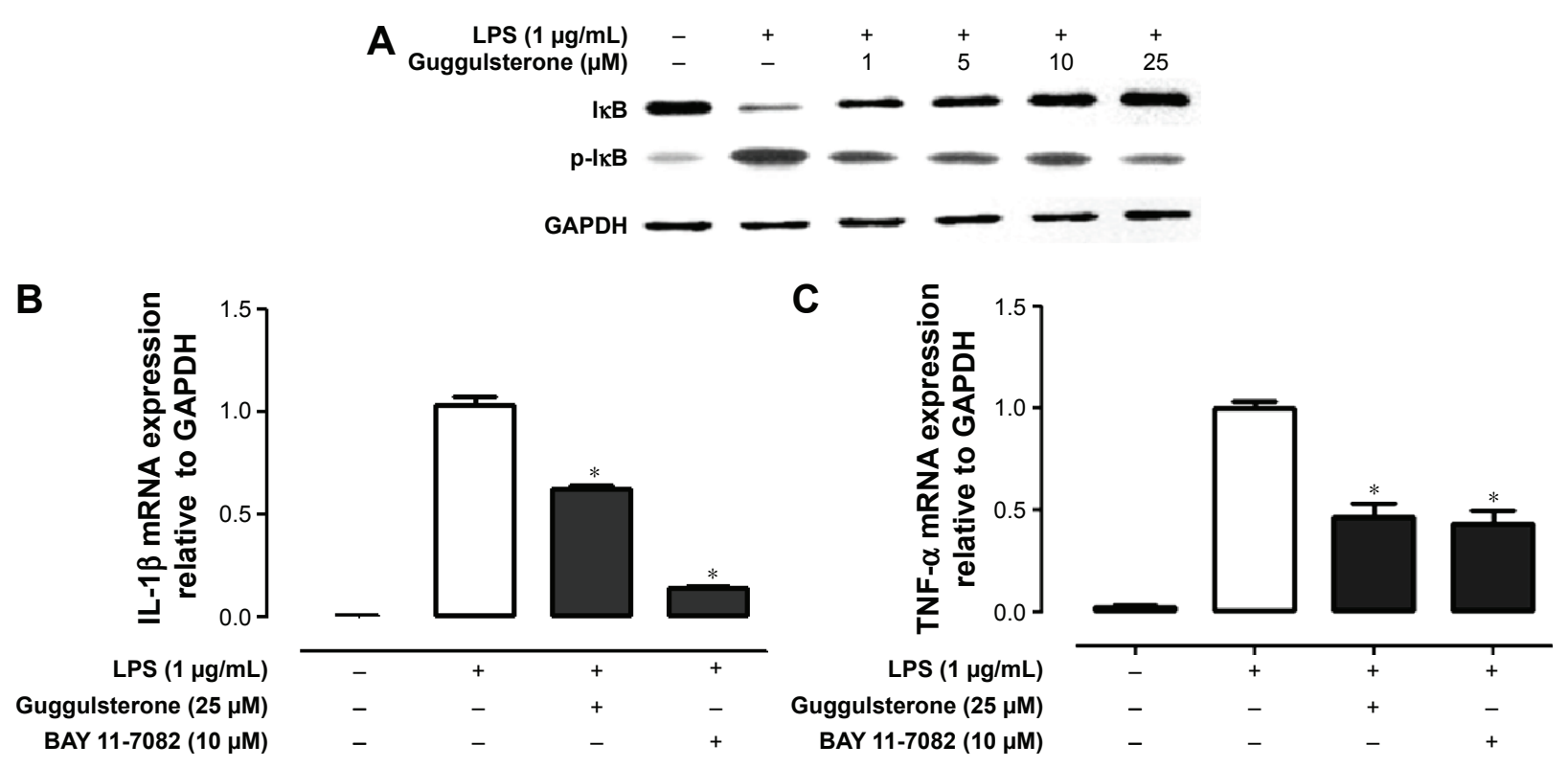

Figure 2 GS inhibited LPS-induced NF- $\kappa B$ pathway in Raw264.7 cells.

Notes: (A) Cells were incubated with GS at indicated concentrations (I, 2.5, 5, 10, I2.5, and $25 \mu \mathrm{M})$ for 4 hours and then stimulated with I $\mu \mathrm{g} / \mathrm{mL}$ LPS for 30 minutes. After treatments, phosphorylation of IKB was demonstrated by immunoblot. Level of GAPDH was used as control. mRNA expression of (B) IL-I $\beta$ and (C) TNF- $\alpha$ relative to GAPDH is presented. GS and BAY II-7082 inhibited proinflammatory cytokines mRNA expression in LPS-stimulated Raw264.7 cells through interfering with NF- $\mathrm{B}$ activation. Data are shown as relative fold change after normalization to GAPDH and expressed as mean \pm SD of the three independent experiments. *P $<0.05$ as compared to LPS alone.

Abbreviations: GS, guggulsterone; NF-אB, nuclear factor-kappaB; LPS, lipopolysaccharide; GAPDH, glyceraldehyde 3-phosphate dehydrogenase; IL-I $\beta$, interleukin I $\beta$; TNF- $\alpha$, tumor necrosis factor-alpha; SD, standard deviation.

$\mathrm{NF}-\kappa \mathrm{B}$ is a ubiquitous transcription factor, which has a central role in LPS-induced inflammatory responses. In resting macrophages, NF- $\mathrm{KB}$ is inactive and sequestered in the cytoplasm through binding with I $\mathrm{\kappa B}$. Interaction of LPS with TLR4 leads to the activation of NF- $\mathrm{KB}$ through

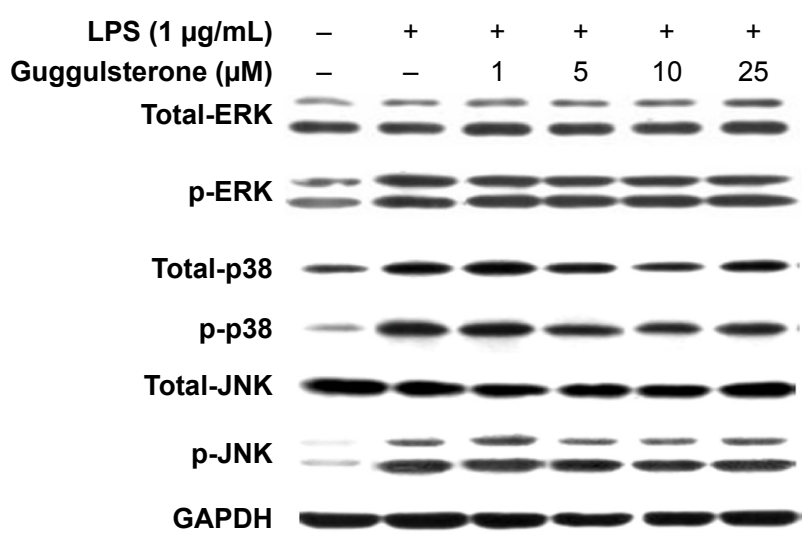

Figure 3 Effect of GS on phosphorylation of ERKI/2, JNK, and p38 in LPS-stimulated Raw264.7 cells.

Notes: Cells were incubated with GS at indicated concentrations (I, 2.5, 5, 10 , 12.5 , and $25 \mu \mathrm{M}$ ) for 4 hours and then stimulated with I $\mu \mathrm{g} / \mathrm{mL}$ LPS for 30 minutes. After treatments, the cells were lysed for protein extraction. Phosphorylation of indicated kinases was demonstrated by immunoblot using specific antibodies and chemiluminescence development. Level of GAPDH was used as control.

Abbreviations: GS, guggulsterone; ERK, extracellular signal-related kinase; JNK, c-Jun N-terminal kinase; p38, p38 mitogen-activated protein kinase; LPS, lipopolysaccharide; GAPDH, glyceraldehyde 3-phosphate dehydrogenase. phosphorylation and degradation of I $\kappa \mathrm{B}$, followed by nuclear

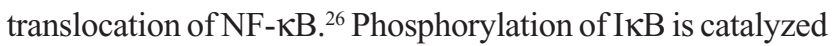
by IKB kinase (IKK) complex. We found that LPS induced a significantly increased level of p-IKB in the Raw264.7 cells, which was restored by GS treatment. Corresponding to the changes in IKB phosphorylation, LPS-induced elevation of IL- $1 \beta$ and TNF- $\alpha$ mRNA expression was reduced in response to GS treatment. These data suggest that GS exerts anti-inflammatory activity through inhibition of NF- $\mathrm{KB}$ activation. Use of I $\mathrm{B}$ inhibitor, BAY 11-7082, which blocks phosphorylation of $\mathrm{I} \kappa \mathrm{B}$, resulted in a relatively low expression of IL-1 $\beta$ compared with that of GS-treated cells, whereas GS and BAY 11-7082 shared similar suppression effects on TNF- $\alpha$ expression. It is known that LPS induces biphasic activation of NF- $\mathrm{kB}{ }^{26}$ LPS-induced early NF- $\kappa \mathrm{B}$ activity initiates production of proinflammatory cytokines such as TNF- $\alpha$ and IL-1 $\beta$, which in turn induce the late NF- $\kappa B$ activation. ${ }^{26,27}$ Our results suggest that GS suppressed LPS-induced inflammatory response through interfering with late NF- $\mathrm{KB}$ activation.

MAPK signaling pathway has been reported to be involved in the regulation of proinflammatory cytokine expression in activated macrophages. In the presence of LPS, signal transduction is initiated with the formation of LPS/TLR/MD2 complex, leading to activation of MAPK 
pathway cascade. ${ }^{7,28}$ Researches have shown that p38 MAPK pathway is associated with expression of TNF- $\alpha$, IL-1 $\beta$, IL-6, and IL-8. ${ }^{29-31}$ In our study, ERK1/2, JNK, and p38 were activated in LPS-stimulated Raw264.7 cells in parallel with elevated expression of proinflammatory cytokines. GS treatment showed no alteration in levels of p-ERK, p-JNK, or p-p38, but increased expression of cytokines was abolished. It is suggested that anti-inflammatory property of GS is not mediated by ERK, JNK, or p38 MAPK pathways in part.

\section{Conclusion}

In conclusion, we provide evidence highlighting the immunomodulatory activity of GS via the suppression of NF- $\mathrm{BB}$ activation but not ERK, JNK, or p38 MAPK pathways in LPS-treated Raw264.7 cells. Our results are expected to contribute to the understanding of mechanism of regulating chronic inflammation, such as sepsis, by using a natural plant component.

\section{Acknowledgments}

This study was supported by grants from the Xiamen Medical College, Young Foundation of Fujian Provincial Health Department (2010-2-68), Young Talent Foundation of Fujian Provincial Health Department (2013ZQN-ZD-31), and Promotion Program for Young and Middle-aged Teacher in Science and Technology Research of Huaqiao University (ZQN-YX205).

\section{Disclosure}

The authors report no conflicts of interest in this work.

\section{References}

1. Parker LC, Prince LR, Sabroe I. Translational mini-review series on Toll-like receptors: networks regulated by Toll-like receptors mediate innate and adaptive immunity. Clin Exp Immunol. 2007;147:199-207.

2. Moonis M, Ahmad I, Bachhawat BK. Macrophages in host defence - an overview. Indian J Biochem Biophys. 1992;29:115-122.

3. Schwartz Y, Svistelnik AV. Functional phenotypes of macrophages and the M1-M2 polarization concept. Part I. Proinflammatory phenotype. Biochemistry (Mosc). 2012;77:246-260.

4. Castranova V. Role of nitric oxide in the progression of pneumoconiosis. Biochemistry (Mosc). 2004;69:32-37.

5. MacMicking J, Xie QW, Nathan C. Nitric oxide and macrophage function. Annu Rev Immunol. 1997;15:323-350.

6. An H, Xu H, Yu Y, et al. Up-regulation of TLR9 gene expression by LPS in mouse macrophages via activation of NF-kappaB, ERK and p38 MAPK signal pathways. Immunol Lett. 2002;81:165-169.

7. Bode JG, Ehlting C, Haussinger D. The macrophage response towards LPS and its control through the p38(MAPK)-STAT3 axis. Cell Signal. 2012;24:1185-1194.

8. Urizar NL, Liverman AB, Dodds DT, et al. A natural product that lowers cholesterol as an antagonist ligand for FXR. Science. 2002; 296:1703-1706.
9. Samudio I, Konopleva M, Safe S, et al. Guggulsterones induce apoptosis and differentiation in acute myeloid leukemia: identification of isomerspecific antileukemic activities of the pregnadienedione structure. Mol Cancer Ther. 2005;4:1982-1992.

10. Wang X, Greilberger J, Ledinski G, et al. The hypolipidemic natural product Commiphora mukul and its component guggulsterone inhibit oxidative modification of LDL. Atherosclerosis. 2004;172:239-246.

11. Wang WC, Uen YH, Chang ML, et al. Protective effect of guggulsterone against cardiomyocyte injury induced by doxorubicin in vitro. $B M C$ Complement Altern Med. 2012;12:138.

12. Chander R, Rizvi F, Khanna AK, et al. Cardioprotective activity of synthetic guggulsterone (E and Z-isomers) in isoproterenol induced myocardial ischemia in rats: a comparative study. Indian $J$ Clin Biochem. 2003;18:71-79.

13. Sharma B, Salunke R, Srivastava S, et al. Effects of guggulsterone isolated from Commiphora mukul in high fat diet induced diabetic rats. Food Chem Toxicol. 2009;47:2631-2639.

14. Kim JM, Kim SH, Ko SH, et al. The guggulsterone derivative GG-52 inhibits NF-kappaB signaling in gastric epithelial cells and ameliorates ethanol-induced gastric mucosal lesions in mice. Am J Physiol Gastrointest Liver Physiol. 2013;304:G193-G202.

15. Mencarelli A, Renga B, Palladino G, et al. The plant sterol guggulsterone attenuates inflammation and immune dysfunction in murine models of inflammatory bowel disease. Biochem Pharmacol. 2009;78: 1214-1223.

16. Noh EM, Chung EY, Youn HJ, et al. Cis-guggulsterone inhibits the IKK/NF-kappaB pathway, whereas trans-guggulsterone inhibits MAPK/AP-1 in MCF7 breast cancer cells: guggulsterone regulates MMP9 expression in an isomer-specific manner. Int J Mol Med. 2013; 31:393-399.

17. Yang MH, Lee KT, Yang S, et al. Guggulsterone enhances antitumor activity of gemcitabine in gallbladder cancer cells through suppression of NF-kappaB. J Cancer Res Clin Oncol. 2012;138:1743-1751.

18. Macha MA, Matta A, Chauhan SS, et al. Guggulsterone (GS) inhibits smokeless tobacco and nicotine-induced NF-kappaB and STAT3 pathways in head and neck cancer cells. Carcinogenesis. 2011;32: 368-380.

19. Morimoto Y, Izumi H, Kuroda E. Significance of persistent inflammation in respiratory disorders induced by nanoparticles. J Immunol Res. 2014;2014:962871.

20. Rossol M, Heine H, Meusch U, et al. LPS-induced cytokine production in human monocytes and macrophages. Crit Rev Immunol. 2011; 31:379-446.

21. Ferwerda B, McCall MB, Verheijen K, et al. Functional consequences of toll-like receptor 4 polymorphisms. Mol Med. 2008;14:346-352.

22. Guha M, Mackman N. LPS induction of gene expression in human monocytes. Cell Signal. 2001;13:85-94.

23. Youn HS, Ahn SI, Lee BY. Guggulsterone suppresses the activation of transcription factor IRF3 induced by TLR3 or TLR4 agonists. Int Immunopharmacol. 2009;9:108-112.

24. Kizaki T, Shirato K, Sakurai T, et al. Beta2-adrenergic receptor regulate Toll-like receptor 4-induced late-phase NF-kappaB activation. Mol Immunol. 2009;46:1195-1203.

25. Kang YJ, Kim SO, Shimada S, et al. Cell surface 4-1BBL mediates sequential signaling pathways 'downstream' of TLR and is required for sustained TNF production in macrophages. Nat Immunol. 2007;8: 601-609.

26. Han SJ, Ko HM, Choi JH, et al. Molecular mechanisms for lipopolysaccharide-induced biphasic activation of nuclear factor-kappa B (NF-kappa B). J Biol Chem. 2002;277:44715-44721.

27. Han Y, Brasier AR. Mechanism for biphasic rel A. NF-kappaB1 nuclear translocation in tumor necrosis factor alpha-stimulated hepatocytes. J Biol Chem. 1997;272:9825-9832.

28. Rao KM. MAP kinase activation in macrophages. J Leukoc Biol. 2001; 69:3-10. 
29. Yougbare I, Boire G, Roy M, et al. NCS 613 exhibits anti-inflammatory effects on PBMCs from lupus patients by inhibiting p38 MAPK and NF-kappaB signalling pathways while reducing proinflammatory cytokine production. Can J Physiol Pharmacol. 2013;91:353-361.

30. Armstrong J, Harbron C, Lea S, et al. Synergistic effects of p38 mitogenactivated protein kinase inhibition with a corticosteroid in alveolar macrophages from patients with chronic obstructive pulmonary disease. J Pharmacol Exp Ther. 2011;338:732-740.
31. Neuder LE, Keener JM, Eckert RE, et al. Role of p38 MAPK in LPS induced pro-inflammatory cytokine and chemokine gene expression in equine leukocytes. Vet Immunol Immunopathol. 2009;129:192-199.

\section{Publish your work in this journal}

Drug Design, Development and Therapy is an international, peerreviewed open-access journal that spans the spectrum of drug design and development through to clinical applications. Clinical outcomes, patient safety, and programs for the development and effective, safe, and sustained use of medicines are a feature of the journal, which has also been accepted for indexing on PubMed Central. The manuscript management system is completely online and includes a very quick and fair peer-review system, which is all easy to use. Visit http://www.dovepress.com/testimonials.php to read real quotes from published authors.

Submit your manuscript here: http://www.dovepress.com/drug-design-development-and-therapy-journal 